\title{
Reclamation of Lithium Cobalt Oxide from Waste Lithium Ion Batteries to Be Used as Recycled Active Cathode Materials
}

\author{
Rakibul Qadir ${ }^{1,2 *}$, Fahmida Gulshan ${ }^{1}$ \\ ${ }^{1}$ Dept. of Materials and Metallurgical Engineering, Bangladesh University of Engineering and Technology, Dhaka, Bangladesh \\ ${ }^{2}$ Pilot Plant and Process Development Center, Bangladesh Council of Scientific and Industrial Research, Dhaka, Bangladesh \\ Email: *mdrqadir@gmail.com
}

How to cite this paper: Qadir, R. and Gulshan, F. (2018) Reclamation of Lithium Cobalt Oxide from Waste Lithium Ion Batteries to Be Used as Recycled Active Cathode Materials. Materials Sciences and Applications, 9, 142-154.

https://doi.org/10.4236/msa.2018.91010

Received: October 2, 2017

Accepted: January 15, 2018

Published: January 18, 2018

Copyright (c) 2018 by authors and Scientific Research Publishing Inc. This work is licensed under the Creative Commons Attribution International License (CC BY 4.0).

http://creativecommons.org/licenses/by/4.0/

\begin{abstract}
Waste laptop batteries (Type-Lithium ion) have been collected and manually dismantled in the current work. Active electrode materials were scraped off from the copper current collector and polyethylene separators. The aluminum current collectors were found to be severely damaged and attached with the electrode material. It was treated with $\mathrm{NaOH}$ later to be recovered as $\mathrm{Al}_{2} \mathrm{O}_{3}$. The leaching of $\mathrm{LiCoO}_{2}$ was done by $3 \mathrm{M} \mathrm{HCl}$ aided by $5 \% \mathrm{H}_{2} \mathrm{O}_{2}$ at $60^{\circ} \mathrm{C}$ from the scraped active electrode materials $\left(\mathrm{LiCoO}_{2}\right.$ and graphite) leaving the graphite completely. Co was precipitated as hydroxide by the addition of $\mathrm{NaOH}$ and later converted to $\mathrm{Co}_{3} \mathrm{O}_{4}$. The remaining solution was treated with saturated $\mathrm{Na}_{2} \mathrm{CO}_{3}$ to acquire $\mathrm{Li}_{2} \mathrm{CO}_{3}$ as crystalline precipitate with high purity. The recovery of $\mathrm{Co}$ and $\mathrm{Li}$ was $99 \%$ and $30 \%$, respectively. $\mathrm{Co}_{3} \mathrm{O}_{4}$ and $\mathrm{Li}_{2} \mathrm{CO}_{3}$ were mixed in stoichiometric proportions and calcined around $950^{\circ} \mathrm{C}$ with air supply to achieve $\mathrm{LiCoO}_{2}$ successfully.
\end{abstract}

\section{Keywords}

$\mathrm{LiCoO}_{2}$, Lithium Ion Battery (LIB), Reclamation of $\mathrm{LiCoO}_{2}$, Leaching, Active Cathode Materials

\section{Introduction}

In the current world of technology, efficient connectivity greatly depends on mobility. Portable electronic devices which have evolved almost as our electronic organs thrive on rechargeable power sources-currently on lithium ion batteries (LIBs). The construction of such batteries utilizes Lithium compounds-Lithium Cobalt Oxide $\left(\mathrm{LiCoO}_{2}\right)$ being the most popular of them all-as active cathode materials. $\mathrm{LiCoO}_{2}$ acts as storage of electricity while charging and as a source 
while discharging. This costly component turns into the major environmental danger after the service life of the battery if improperly disposed [1]. The cobalt in such materials posses threats to the ecology being a heavy metal. Lithium being explosive in nature in the elemental form carries the risk of accidental explosion and toxic gas emission while burnt off or ill-treated during informal recycling [2] [3].

LIBs find their use commonly in laptop computers, cellular phones, camera, rechargeable lights and numerous modern life appliances and very recently in electric vehicles. An estimated total production of 12.7 billion mobile phones, 94.4 million laptop computers, and 768.9 million digital cameras [4] was reported by the United Nations till 2010. Clearly equal number of LIBs is to be handled after their lifetime. For the year 2016 alone, 4.7 billion unique mobile phone subscribers were reported [5]. Estimated 135.98 million [6] domestic mobile phone subscribers were present in mid 2017, which forecasts the number of LIBs joining the waste stream very soon. Approximately 0.3 million [7] computers are being consumed each year in the country, of which a substantial amount is the laptop computers having LIBs.

The importance of extractable metals from LIBs for a country like Bangladesh with no primary metallic sources cannot possibly be over exaggerated, while sorted electronic waste stream has already found its way to efficient recycling facilities abroad. In addition, if the key ingredient- $\mathrm{LiCoO}_{2}-$ can be recycled locally, domestic manufacturing of LIB could be possible empowering national economy.

From the late ninety's, researchers have been working on the development of recycling opportunities from LIBs. Thermal [8] and Mechanical [9] treatments have been experimented successfully. Solvent extraction by PC-88A [10], Acorga M5640 [11] and Cyanex 272 [11] [12] have yielded great recovery rates, however, the availability and post treatment for such solvents along with the cost associated needs much consideration. Although dissolution by $\mathrm{N}$-methylpyrrolidone (NMP) has been proven [2] [13] helpful, the authors found difficulties with the output (trials with DMSO were also unsuccessful). Chemical leaching with organic [14] [15] or inorganic [16] [17] acids and subsequent precipitation of metallic salts to be used as precursors for the formation of active cathode materialsdeems to be the most attractive option till today due to the low cost associated and process simplicity. The current work utilizes $\mathrm{HCl}$ leaching of $\mathrm{LiCoO}_{2}$ aided by $\mathrm{H}_{2} \mathrm{O}_{2}$ as reducing agent after laborious yet simple manual dismantling of lithium ion batteries from laptop computers. Cobalt and lithium were then precipitated prudentially by basic treatments as $\mathrm{Co}(\mathrm{OH})_{2}$ (later turned to $\mathrm{Co}_{3} \mathrm{O}_{4}$ ) and $\mathrm{Li}_{2}\left(\mathrm{CO}_{3}\right)$. Finally they were mixed and calcined to produce $\mathrm{LiCoO}_{2}$.

\section{Materials and Methods}

\subsection{Materials}

Waste laptop batteries (Brand: HP, Type: Li ion, 6 cell) were collected from the local scrap market (Elephant road, Dhanmondi, Dhaka). The chemical reagents 
( $\mathrm{HCl}, \mathrm{NaOH}, \mathrm{H}_{2} \mathrm{O}_{2}$ and $\mathrm{Na}_{2} \mathrm{CO}_{3}$ ) used in this study were of analytical grades (Merck, Germany and Scherlue, Spain). For all purposes de-ionized water ( $\mathrm{pH}$ 6.5 - 7.5) was used.

\subsection{Methods}

For the estimation of carbon and organic contents, a CHNS-O (Brand: Thermo Fisher, Model: Flash 2000, Origin: USA) was used. To identify the metallic elements in the active electrode materials, a WDXRF (Brand: Shimadzu, Model: LAB Center XRF-1800, Origin: Japan) was used. Phase identification data of several intermediate products and raw materials were obtained using XRD (Brand: Bruker, Model: D8 Advance, Origin: Germany). Concentration of ions in different intermediate solutions was characterized by an AAS (Brand: Shimadzu, Model: AA7000, Origin: Japan). A (Brand: Jeol, Model: 71031SE2A, Origin: Japan) FESEM was used to acquire micrographs.

\section{Experimental}

\subsection{Mechanical Breaking}

Waste laptop batteries were mechanically broken with pliers to separate the plastic casing, connectors, thermo-couples and additional materials from the 6 cell assembly. Each cell was discharged by dipping in a $5 \% \mathrm{NaCl}$ solution for 2 hours. The cells were then broke mechanically under a fume hood with pliers and a screw driver to unravel the coiled PE separators and the electrodes to be kept on a steel tray inside the fume hood to naturally dry for 3 days.

\subsection{Separation of Aluminum and Active Electrode Materials}

The $\mathrm{Cu}$ electrodes and PE separators were then manually scraped to remove active electrode materials (AEM, consisting graphite and $\mathrm{LiCoO}_{2}$ ) as far as possible. Further scraping was done by the wet brushing of PE separators with DM water and a brush.

The $\mathrm{Al}$ electrodes and attached AEM were treated with $1 \mathrm{M} 500 \mathrm{ml} \mathrm{NaOH}$. The $\mathrm{Al}$ foil reacted with the $\mathrm{NaOH}$ to form $\mathrm{Na}_{2} \mathrm{Al}_{2} \mathrm{O}_{4}$ and the AEM got separated. This portion of AEM was treated again with $1 \mathrm{M} 100 \mathrm{ml} \mathrm{NaOH}$ to assure any un-reacted $\mathrm{Al}$ got in the solution. The solution (total $600 \mathrm{ml}$ ) was then filtered to recover the AEM and washed subsequently with $\mathrm{DM}$ water before drying at $100^{\circ} \mathrm{C}$ overnight. The filtrate was treated with dry $\mathrm{CO}_{2}$ bubbling through it with rigorous stirring. Eventually the solution turned white and $\mathrm{Al}(\mathrm{OH})_{3}$ precipitation formed. It was observed that this process was accelerated in warm $\left(\sim 50^{\circ} \mathrm{C}\right)$ condition. It was then filtered and washed before drying overnight at $100^{\circ} \mathrm{C}$. The filtrate is again treated with dry $\mathrm{CO}_{2}$ to recover additional $\mathrm{Al}(\mathrm{OH})_{3}$ precipitates. The amount achieved from this second treatment was reasonably small. It was then filtered and dried the same way. A portion from the filtrate was taken for Atomic Absorption Spectrometer (AAS) to quantify any remaining amount of $\mathrm{Al}$. The dried $\mathrm{Al}(\mathrm{OH})_{3}$ was characterized with X-Ray Diffractometer to identify 
any possible impurities and confirm the $\mathrm{Al}(\mathrm{OH})_{3}$ phase(s) formed. It was finally treated at $600^{\circ} \mathrm{C}$ for 4 hours to get $\mathrm{Al}_{2} \mathrm{O}_{3}$. The separated AEM were ball milled to fines. The milled AEM was analyzed in an elemental analyzer (CHNS-O) to quantify the amount of graphite and organic materials remaining. Also X-Ray fluorescence was done to reconfirm the type of active cathode material.

\subsection{Leaching}

The leaching and simultaneous removal of graphite from the AEM was done by $3 \mathrm{M} \mathrm{HCl}$ with a solid to liquid ration of $1: 20$, aided by $5 \% \mathrm{H}_{2} \mathrm{O}_{2}$. The solution was then filtered to acquire the graphite particles on the filter paper to be washed and dried subsequently. The dried graphite powder was then analyzed by XRD to confirm the absence of $\mathrm{LiCoO}_{2}$.

\subsection{Cobalt and Lithium Recovery}

A portion of this solution was analyzed in the AAS to estimate the amount of leached $\mathrm{Co}$ and $\mathrm{Li}$. Rest of the solution was treated with $65 \mathrm{ml} 4 \mathrm{M} \mathrm{NaOH}$ (per $100 \mathrm{ml}$ leach solution) to reclaim $\mathrm{Co}$ as cobalt hydroxide precipitates at near $\mathrm{pH}$ 11. The $\mathrm{Co}(\mathrm{OH})_{2}$ obtained was then treated at $600^{\circ} \mathrm{C}$ for 3 hour to get $\mathrm{Co}_{3} \mathrm{O}_{4}$. The remaining solution was condensed to half of the initial volume by heating. Later it was treated with saturated $\mathrm{Na}_{2}\left(\mathrm{CO}_{3}\right)$ and boiled for some time to get a precipitate of $\mathrm{Li}_{2} \mathrm{CO}_{3}$. The solutions-before and after the $\mathrm{Li}$ separation-were also taken for AAS analysis to measure the Co and Li recoveries respectively.

\section{5. $\mathrm{LiCoO}_{2}$ Formation}

To synthesize $\mathrm{LiCoO}_{2}$ stoichiometric proportions of $\mathrm{Co}_{3} \mathrm{O}_{4}$ and $\mathrm{Li}_{2} \mathrm{CO}_{3}$ was calculated to be 1:1.5 (molar) according to the following equation:

$$
6 \mathrm{Li}_{2} \mathrm{CO}_{3}(\mathrm{~s})+4 \mathrm{Co}_{3} \mathrm{O}_{4}(\mathrm{~s})+\mathrm{O}_{2}(\mathrm{~g}) \stackrel{\Delta}{\longrightarrow} 12 \mathrm{LiCoO}_{2}(\mathrm{~s})+6 \mathrm{CO}_{2}(\mathrm{~g})
$$

A set of samples of total mass $1 \mathrm{gm}$ was prepared by mixing the weighted reactants in a mortar-pestle and pressing in a die up to $20 \mathrm{kpa}$ to form green tablets. The tablets were then sintered in a tube furnace with and without air supply. The sintering cycles were similar to Figure 1.

The reaction suggests that, $\mathrm{O}_{2}$ is required for the fulfillment of the reaction. Hence, later experiments were done with an additional air flow provided by a pump attached with the tube furnace. The tablets were characterized by XRD after each time period of sintering, to identify the phases formed.

\section{Results}

To evaluate the recovery process and possible electrode material loss, the physical dimensions of the electrode current collectors and the PP separators were measured (Figure 2).

Table 1 and Table 2 summarize the nominal amounts of the overall constituents of LIB. 


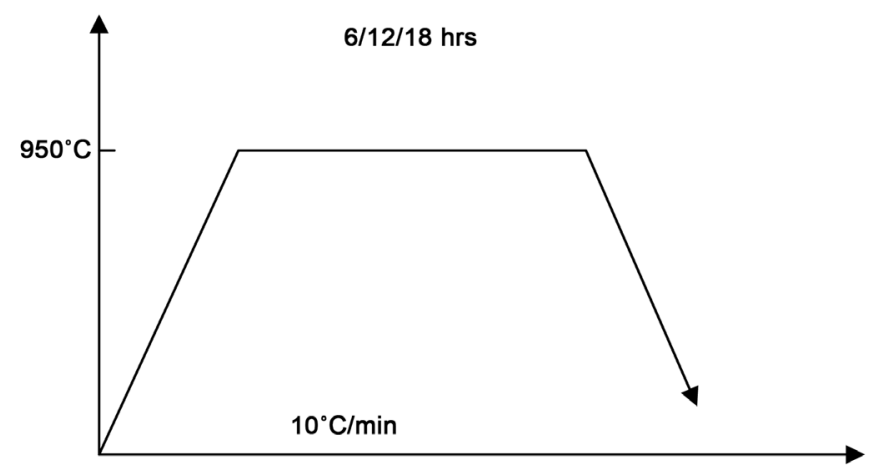

Figure 1. Sintering cycle for the synthesis of $\mathrm{LiCoO}_{2}$.
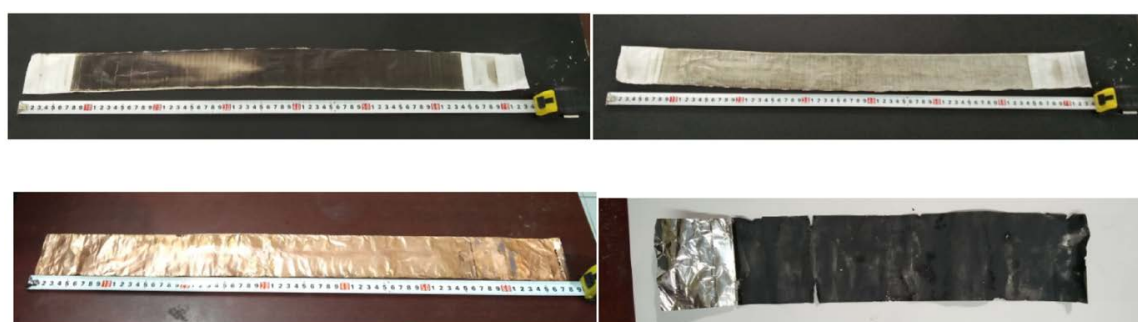

Figure 2. Separators (top) and Electrodes (bottom) of LIB.

Table 1. Measurements of the electrodes and separator.

\begin{tabular}{ccccc}
\hline Measurements & Length, $\mathbf{m m}$ & Width, $\mathbf{m m}$ & Thickness, $\boldsymbol{\mu m}$ & Calculated mass, gm \\
\hline $\mathrm{Cu}$ & 680 & 58 & 8 & 16.96236 \\
$\mathrm{Al}$ & 680 & 57 & 12 & 7.534944 \\
PE Separator & 740 & 58 & 14 & 6.82119 \\
\hline
\end{tabular}

Table 2. Amount of different constituents of a LIB.

\begin{tabular}{ccc} 
Constituent & gm & $\%$ \\
\hline Cell Assembly & 316.0 & 100 \\
Plastic Casing, Connector, Thermocouple & 50.0 & 15.8 \\
6 Cell & 266.0 & 84.2 \\
Cell Casing, separators, parts & 51.0 & 16.1 \\
Cu Electrodes & 17.2 & 5.4 \\
PE Separator & 6.8 & 2.2 \\
Cathode Material & 130.9 & 41.4 \\
graphite & 31.6 & 10.0 \\
Al Electrode & 7.5 & 2.4 \\
Organics and Volatiles & 20.9 & 6.6 \\
\hline
\end{tabular}

\subsection{Active Electrode Material Identification}

The active electrode materials were identified by X-Ray Fluorescence (XRF) analysis (Table 3). It gave a definite indication that the active cathode material 
Table 3. Amount of different elements in the AEM.

\begin{tabular}{ccccccccc}
\hline & \multicolumn{3}{c}{ XRF Data } & \multicolumn{5}{c}{ CHNSO analyzer Data } \\
\hline Element & $\mathrm{Co}(\%)$ & $\mathrm{Cu}(\%)$ & $\mathrm{Al}(\%)$ & $\mathrm{C} \mathrm{( \% )}$ & $\mathrm{N} \mathrm{( \% )}$ & $\mathrm{H} \mathrm{( \% )}$ & $\mathrm{S} \mathrm{( \% )}$ & $\mathrm{O}(\%)$ \\
\hline Quantity & 96.95 & 1.53 & 1.51 & 45.63 & 0.73 & 0.33 & $\sim 0$ & $\sim 0$ \\
\hline
\end{tabular}

was rich in $\mathrm{Co}$, later identified to be $\mathrm{LiCoO}_{2}$. Lithium cannot be effectively identified by XRF, being a lighter (atomic no: 3) metal. There was an indication of the presence of small amounts of $\mathrm{Cu}$ and $\mathrm{Al}$ in the cathode material, possibly due to corrosion and the dismantling-scraping process.

Also the content of graphite was estimated with an Elemental (C, H, N, S, O) Analyzer. The presence of insignificant amounts of $\mathrm{H}, \mathrm{N}, \mathrm{S}$ and $\mathrm{O}$ indicated that almost all organic materials used were volatile and the remaining was mainly carbon (graphite). From this result, the amount of $\mathrm{LiCoO}_{2}$ in the electrode material was estimated to be $54 \%$ (round figure) to be used in the leaching calculations.

\subsection{Reclamation after Leaching}

The Atomic Absorption Spectroscopy results are Table 4.

It depicts the concentration of metallic ions in solutions achieved in different steps. The phases of the reclamation products were identified by XRD later on.

\subsection{XRD Analysis}

The XRD analysis of active electrode materials (Figure 3 ) detected the presence of Graphite (JCPDS: 65-6212) and $\mathrm{LiCoO}_{2}$. After the removal of Al current collector by $\mathrm{NaOH}$, subsequent $\mathrm{CO}_{2}$ treatment and drying; $\mathrm{Al}(\mathrm{OH})_{3}$ (as Bayerite, JCPDS: 20-0011) was formed, which turned to $\mathrm{Al}_{2} \mathrm{O}_{3}$ (JCPDS: 50-0741) after calcination at $1000^{\circ} \mathrm{C}$ for 1 hour (Figure 4). The residue after leaching was almost pure Graphite (JCPDS: 65-6212). The reclamation products were identified to be $\mathrm{Co}(\mathrm{OH})_{2}$ (later calcined to $\mathrm{Co}_{3} \mathrm{O}_{4}$ (JCPDS: $73-1701$ ) at $650^{\circ} \mathrm{C}$ for 1 hour) and $\mathrm{Li}_{2} \mathrm{CO}_{3}$ (as Zabuyelite, JCPDS: 83-1454) as shown in Figure 5 and Figure 6. $\mathrm{Co}(\mathrm{OH})_{2}$ was amorphous in nature, as a result no crystalline pattern was achieved in the XRD.

The formation of $\mathrm{LiCoO}_{2}$ at $950^{\circ} \mathrm{C}$ for different time durations $(6,12,18$ hours) showed different scenarios (Figure 7). Without air the 6 hour treatment showed the formation of less crystalline $\mathrm{LiCoO}_{2}$ (JCPDS: 50-0653) and an impurity phase, possibly $\mathrm{LiAlO}_{2}$ (JCPDS: 33-0776)-formed in contact with the porcelain boat. After the improvisation of additional $\mathrm{Al}_{2} \mathrm{O}_{3}$ layer below the green tablet, the 12 hour treatment showed much crystalline $\mathrm{LiCoO}_{2}$ and $\mathrm{Co}_{3} \mathrm{O}_{4}$ (JCPDS: 73-1701) and some unidentifiable impurity phase-as an indication of $\mathrm{Li}_{2} \mathrm{CO}_{3}$ loss and incomplete reaction. The 18 hour treatment resulted in $\mathrm{LiCoO}_{2}$, $\mathrm{Co}_{3} \mathrm{O}_{4}$ and $\mathrm{CoO}$ (JCPDS: 77-7548). At this point it seemed conclusive that further treatment will never reach a complete conversion to $\mathrm{LiCoO}_{2}$, as there is a $\mathrm{Li}$ deficiency and a possible tendency of $\mathrm{Co}_{3} \mathrm{O}_{4}$ to convert to $\mathrm{CoO}$ with time under the treatment conditions. 


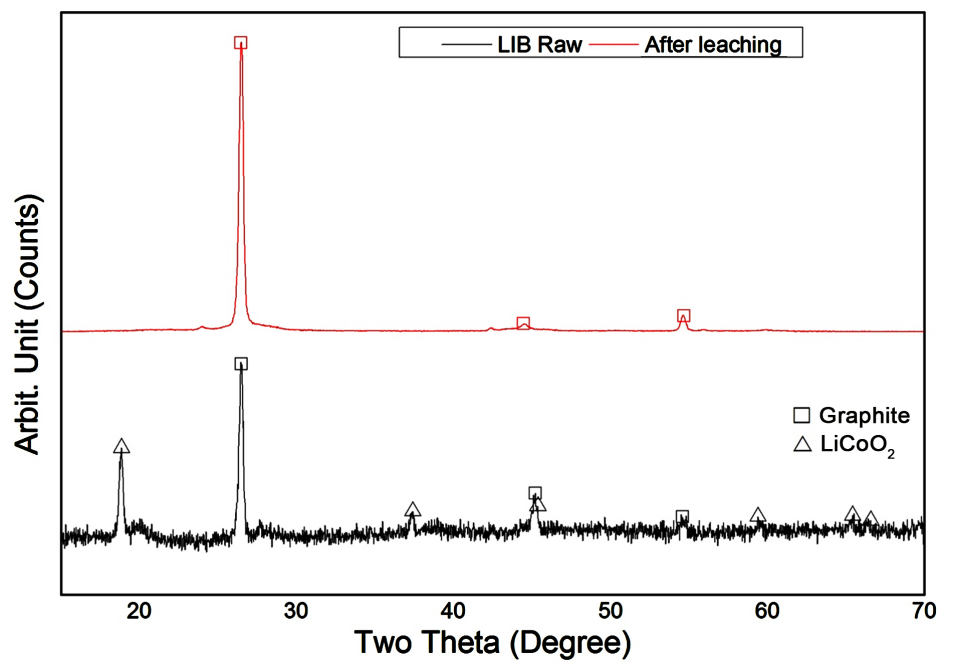

Figure 3. XRD spectra of LIB active cathode materials before and after leaching.

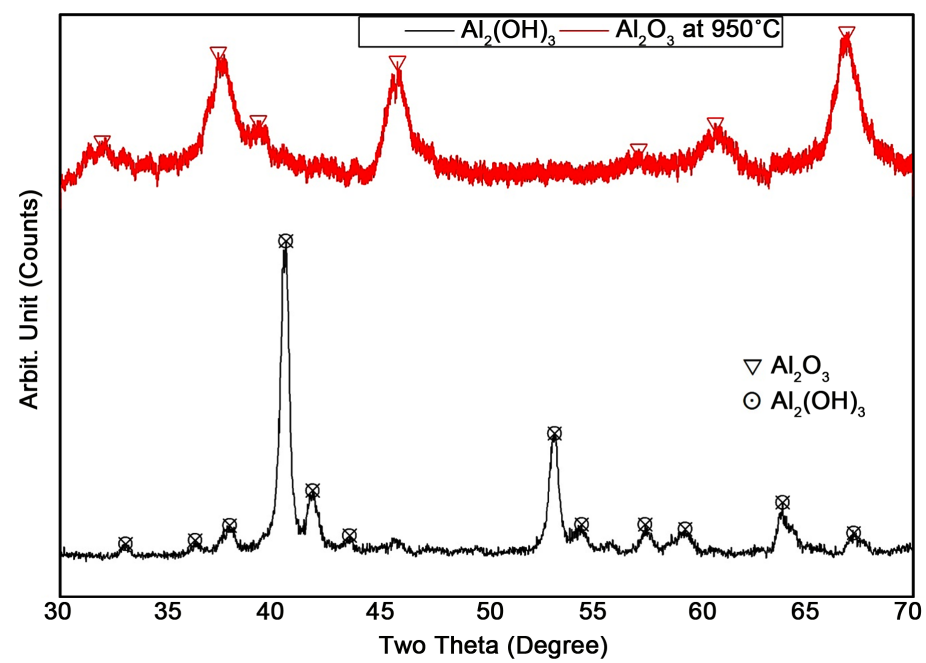

Figure 4. XRD spectra of aluminum extraction as alumina.

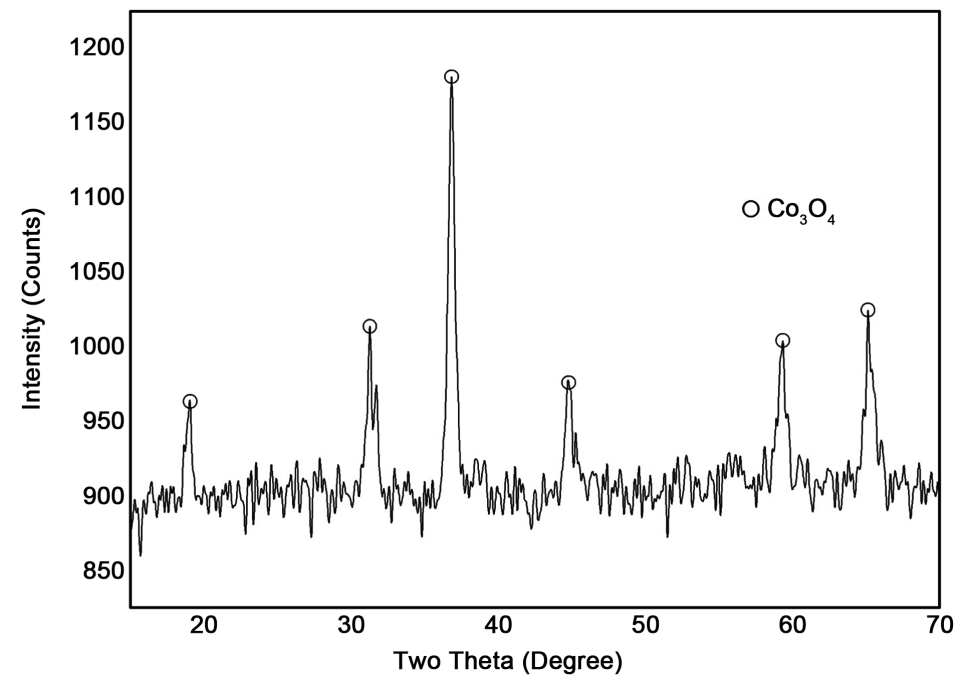

Figure 5. XRD spectra of cobalt oxide synthesis. 


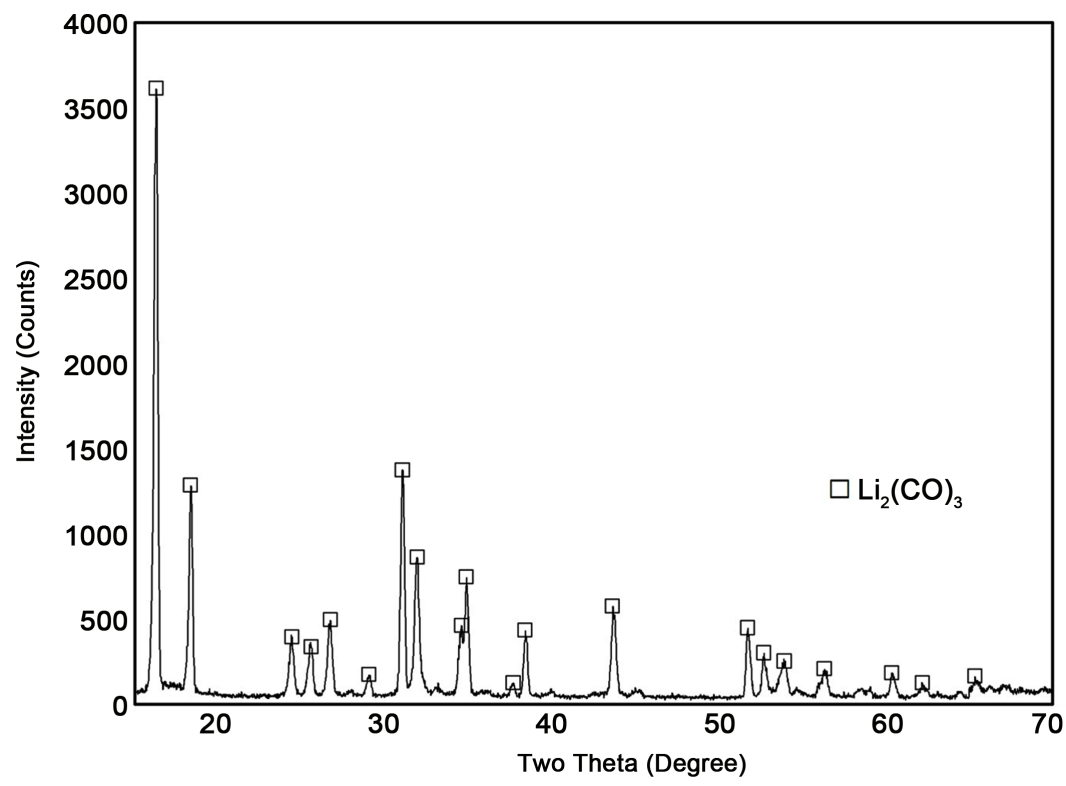

Figure 6. XRD spectra of lithium carbonate synthesis.

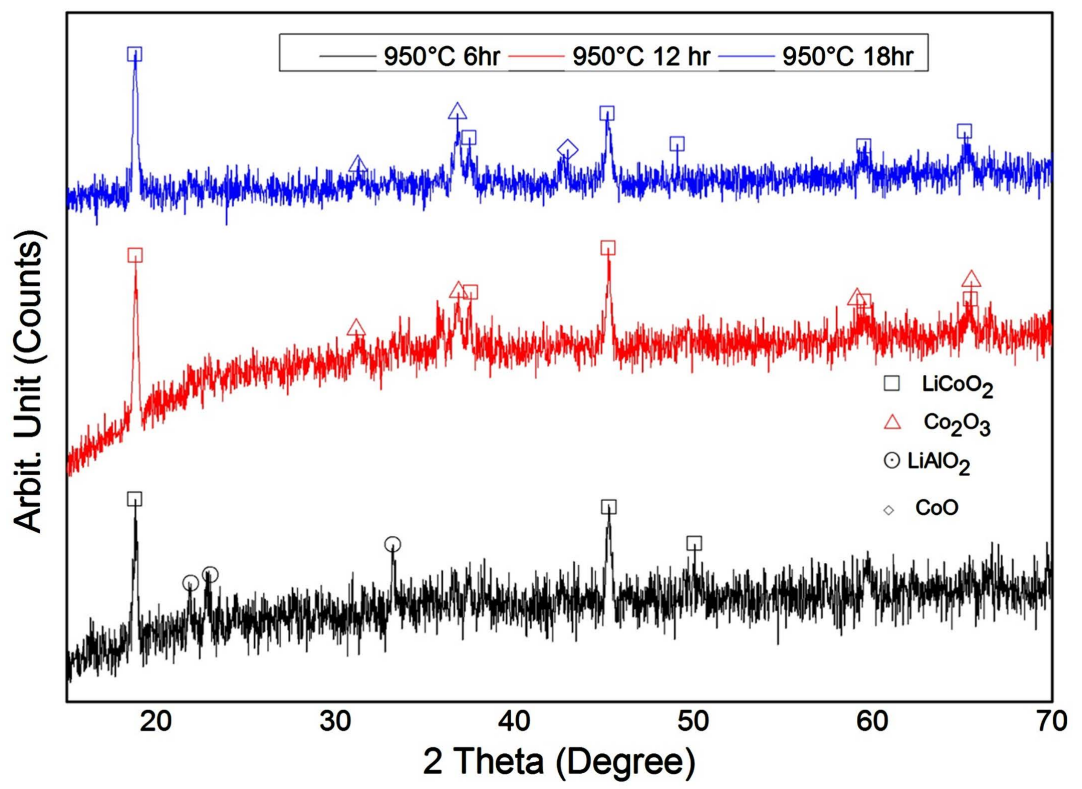

Figure 7. XRD spectra of $\mathrm{LiCoO}_{2}$ synthesis without air.

Table 4. Normalized AAS data of solutions derived at different stages.

\begin{tabular}{cccccc}
\hline \multirow{2}{*}{ Elements } & \multicolumn{5}{c}{ Concentration (ppm) } \\
\cline { 2 - 5 } & $\begin{array}{c}\text { After } \\
\text { Al removal }\end{array}$ & $\begin{array}{c}\text { Leach } \\
\text { Solution }\end{array}$ & $\begin{array}{c}\text { After } \\
\text { Co removal }\end{array}$ & $\begin{array}{c}\text { After } \\
\text { Li removal }\end{array}$ & Recovery (\%) \\
\hline $\mathrm{Li}$ & 0 & 2424.1 & 2407.52 & 1741.5 & $30 \%$ \\
$\mathrm{Cu}$ & 0 & 79.21 & 0 & 0 & - \\
$\mathrm{Al}$ & 248.72 & 198.7 & 105.5 & 108 & - \\
$\mathrm{Co}$ & 0 & 17404 & 1.48 & 0 & $99 \%$ \\
\hline
\end{tabular}


With air, the 6 hour treatment at $950^{\circ} \mathrm{C}$ showed complete crystalline formation of $\mathrm{LiCoO}_{2}$ (JCPDS: 50-0653) with no observable impurities (Figure 8). The product remained the same in the later experiments with prolonged time durations to 12 and 18 hours.

\subsection{SEM Micrographs}

The SEM micrographs shown in Figure 9 depicted irregular shaped grains of synthesized $\mathrm{LiCoO}_{2}$ particles throughout the sintered body.

\section{Discussion}

The dismantling process proved to be an effective one, regardless the labor intensive procedure requiring very little sophistication. Needless to mention, the safety requirements for the dismantling process-fume hood, safety goggles, gloves, etc. were maintained as required.

It was observed that the discharging step of the cells in brine solution initiated some leakage (through the cell vent) to the brine solution and turned the solution color to brown/orange. After some time, the solute precipitates itself and could be effectively filtered. It was assumed to be the commonly used electrolyte (LiPF6) dissolved in Ethylene/Dimethyl Carbonate (EC/DMC) solvent, but the assumption could not be verified as the amount of the filtrate was very small and it projected no crystalline peaks in XRD.

It was found that aqueous stirring or ultrasonication had poor effect on the separation of electrode materials from the metallic electrodes and the polymeric separators. Even when DMSO solvent used for PVDF binder removal, ultrasonication resulted in a separation of small metallic particles. As a result scraping was deemed to be the optimistic way.

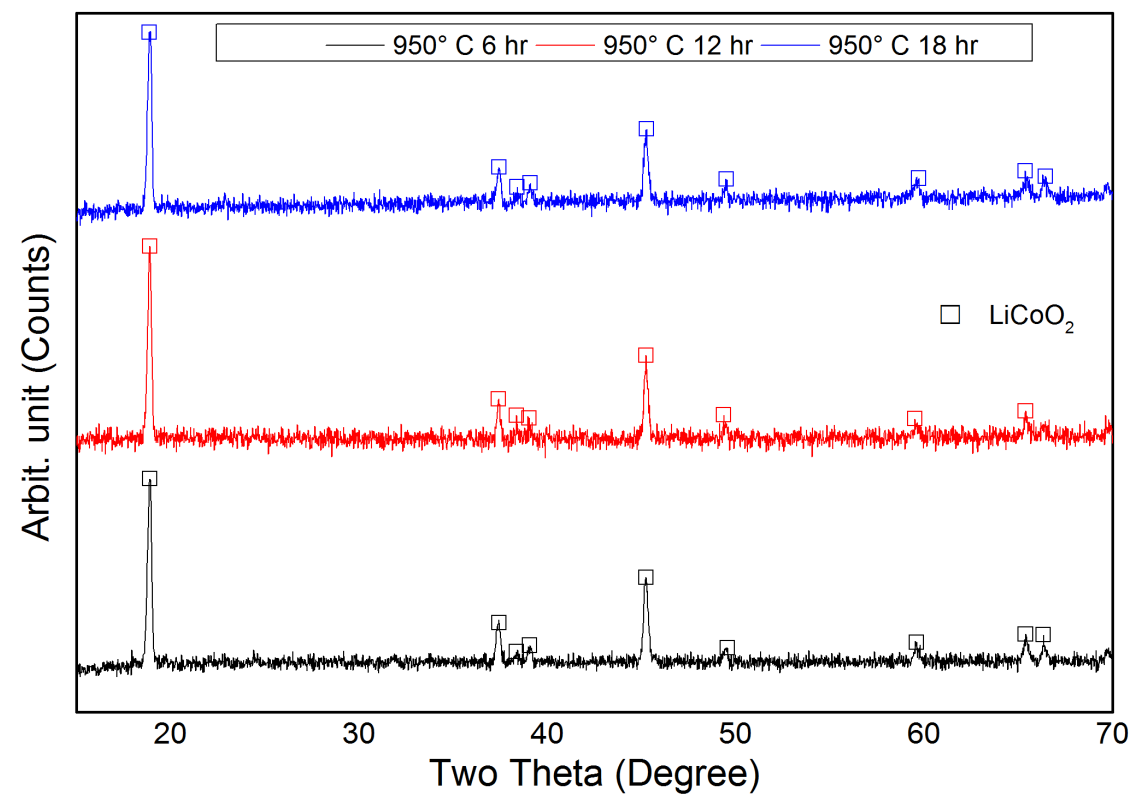

Figure 8. XRD spectra of $\mathrm{LiCoO}_{2}$ Synthesis with air. 

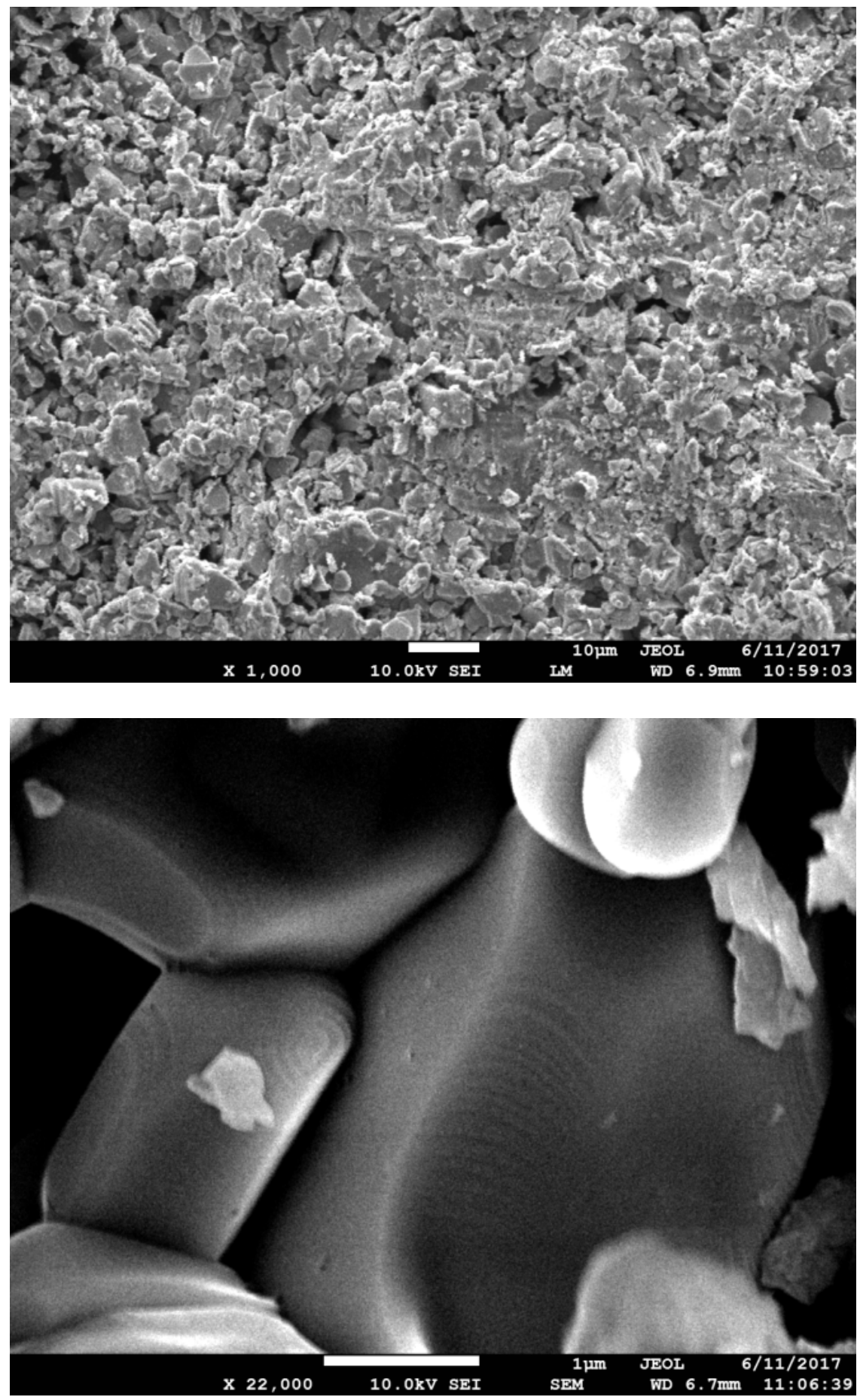

Figure 9. SEM micrographs of synthesized $\mathrm{LiCoO}_{2}$.

The separation was very easy for the $\mathrm{Cu}$ electrodes because it contained mainly graphite on both sides, unlike the $\mathrm{Al}$ electrodes containing graphite as well as $\mathrm{LiCoO}_{2}$ pasted with organic binder(s). As for the PE separators, the scraping process was intermediately successful leaving a good amount of graphite and $\mathrm{LiCoO}_{2}$ still attached on both side. It was later wet scraped. Aluminum Electrodes-in most of the cases-got highly corroded and blistered; possibly due to 
rapid charge/discharge of the cell assembly in actual use. Also the PE separators got black shades in some cases, on the $\mathrm{LiCoO}_{2}$ side due to the same reason. At some points $\mathrm{Al}$ electrodes and AEM got severely attached with the PE separators, possibly because of the severe heat generated due to charging/discharging rapidity. Hence brushing did not help the separation of AEM from $\mathrm{Al}$ electrodes. And negligible amounts of AEM were stuck with the PE separators even after brushing treatment.

The mechanical breakage of the cell assembly and later the cells, readily provided reusable or recyclable $\mathrm{Cu}$ foils, $\mathrm{PE}$ separators, steel casings and plastic (PE, $\mathrm{PP}$, Bakelite, etc.) portions. After the leaching process, the almost pure graphite was achieved which also could find numerous applications. The $\mathrm{NaOH}$ treatment of the cathode dissolved the $\mathrm{Al}$ and was later recovered by the $\mathrm{CO}_{2}$ bubbling. The calcined $\mathrm{Al}(\mathrm{OH})_{3}$ turned to $\mathrm{Al}_{2} \mathrm{O}_{3}$ which has more commercial value.

During experiments it was found that without milling complete leaching of $\mathrm{LiCoO}_{2}$ is tough as it gets trapped inside the graphite. The sheet like layered structure of graphite might also contribute to this effect by trapping $\mathrm{Li}^{+}$ions inside from both the electrolyte and the reaction product of the AEM from charging/discharging cycle. Hence the AEM was milled to fines.

The AAS data confirms that the aluminum current collector has been effectively removed from the cathode. For Cobalt and Lithium ions derived from the leaching of $\mathrm{LiCoO}_{2}, 99 \%$ Co and $30 \% \mathrm{Li}$ could be successfully recovered by the leaching and reclamation process. The Li recovery was low due to some process factors. The solubility of $\mathrm{Li}_{2} \mathrm{CO}_{3}$ in water decreases with increasing temperature. There was no clear indication of completion of the formation of $\mathrm{Li}_{2} \mathrm{CO}_{3}$ at near $100^{\circ} \mathrm{C}$. Subsequent filtering also incorporated the solidification of some $\mathrm{NaCl}$ crystals on the filter paper alongside $\mathrm{Li}_{2} \mathrm{CO}_{3}$, as the solution was already very rich in $\mathrm{Na}^{+}$and $\mathrm{Cl}^{-}$ions. The precipitates were washed at least 5 times with boiling DI water to remove the $\mathrm{NaCl}$. Collaterally some $\mathrm{Li}_{2} \mathrm{CO}_{3}$ were lost in the process. Although the recovery of $\mathrm{Li}_{2} \mathrm{CO}_{3}$ was less, the purity (confirmed by XRD) was very high.

The formation of $\mathrm{LiCoO}_{2}$ depends on various parameters like composition, environment and heating rate, etc.. Researchers [18] [19] have formed $\mathrm{LiCoO}_{2}$ from various raw materials at above $800^{\circ} \mathrm{C}$ with different time duration (close to $24 \mathrm{hrs}$ ). A simple sintering cycle was hence chosen to verify the outcomes.

The addition of air supply with the tube furnace provided tremendous results. The formation of $\mathrm{LiCoO}_{2}$ was complete in all the samples. It could be suggested that under such conditions $\mathrm{LiCoO}_{2}$ formation may be complete even in less time. The authors hope to perform electrochemical tests in order to measure the reversible capacity of the re-synthesized $\mathrm{LiCoO}_{2}$ as future research. It was observed that porcelain boats (made of Kaolinite clay, a form of alumino-silicates) reacts with Lithium salts to produce aluminates or silicates if there is a contact with the green tablet. Hence, a layer of $\alpha-\mathrm{Al}_{2} \mathrm{O}_{3}$ powder was put on the porcelain boats bellow the green tablet(s) later on. 


\section{Conclusion}

In this study, a lithium ion battery assembly has been manually broke into constituent electrodes, separators and other components. A proven reclamation process of $\mathrm{Li}$ and $\mathrm{Co}$ has been investigated by leaching with $\mathrm{HCl}$ and precipitating $\mathrm{Li}$ and $\mathrm{Co}$ compounds by basic treatments. The compounds $\left(\mathrm{Li}_{2}\left(\mathrm{CO}_{3}\right)\right.$ and $\mathrm{Co}_{3} \mathrm{O}_{4}$ ) have been effectively used to synthesize $\mathrm{LiCoO}_{2}$ by a simple thermal treatment. Different characterization techniques have proven the process to be efficient, simple and cost effective.

\section{Acknowledgements}

The work was conducted completely in the Heat Treatment Lab, Pilot Plant and Process Development Center, Bangladesh Council of Scientific and Industrial Research (BCSIR), Dhaka. The authors are greatly thankful to Dr. Abdul Gafur, PSO, IFRD, BCSIR and Dr. A. S. W. Kurny, Professor, Dept. of MME, BUET for their extended help. Dept. of GCE, BUET and BCSIR Laboratories, Dhaka, IFRD, INARS and BTRI, BCSIR also aided with analytical support.

\section{References}

[1] Mukherjee, R., Krishnan, R., Lu, T.M. and Koratkar, N. (2012) Nanostructured Electrodes for High-Power Lithium Ion Batteries. Nano Energy, 1, 518-533. https://doi.org/10.1016/j.nanoen.2012.04.001

[2] Contestabile, M., Panero, S. and Scrosati, B. (1999) A Laboratory-Scale Lithium Battery Recycling Process 1. Journal of Power Sources, 83, 75-78. https://doi.org/10.1016/S0378-7753(99)00261-X

[3] Lupi, C. and Pasquali, M. (2003) Electrolytic Nickel Recovery from Lithium-Ion Batteries. Minerals Engineering, 16, 537-542. https://doi.org/10.1016/S0892-6875(03)00080-3

[4] Wanger, T.C. (2011) The Lithium Future-Resources, Recycling, and the Environment. Conservation Letters, 4, 202-206. https://doi.org/10.1111/j.1755-263X.2011.00166.x

[5] GSMA (2016) 2016 Mobile Industry Impact Report: Sustainable Development Goals.

[6] BTRC (2017) Bangladesh Telecommunication Regulatory Commission Government of the People $\hat{a} €^{\mathrm{TM}} \mathrm{s}$ Republic of Bangladesh.

[7] Rahman, M.A. (2012) E-Waste Management. Cost Manag., 45, 28-35.

[8] Castillo, S., Ansart, F., Laberty-Robert, C. and Portal, J. (2002) Advances in the Recovering of Spent Lithium Battery Compounds. Journal of Power Sources, 112, 247 254. https://doi.org/10.1016/S0378-7753(02)00361-0

[9] Saeki, S., Lee, J., Zhang, Q. and Saito, F. (2004) Co-Grinding $\mathrm{LiCoO}_{2}$ with PVC and Water Leaching of Metal Chlorides Formed in Ground Product. International Journal of Mineral Processing, 74, S373-S378. https://doi.org/10.1016/j.minpro.2004.08.002

[10] Zhang, P., Yokoyama, T., Itabashi, O., Wakui, Y., Suzuki, T.M. and Inoue, K. (1998) Hydrometallurgical Process for Recovery of Metal Values from Spent Nickel-Metal Hydride Secondary Batteries. Hydrometallurgy, 50, 61-75. 
https://doi.org/10.1016/S0304-386X(98)00046-2

[11] Nan, J., Han, D. and Zuo, X. (2005) Recovery of Metal Values from Spent LithiumIon Batteries with Chemical Deposition and Solvent Extraction. Journal of Power Sources, 152, 278-284. https://doi.org/10.1016/j.jpowsour.2005.03.134

[12] Dorella, G. and Mansur, M.B. (2007) A Study of the Separation of Cobalt from Spent Li-Ion Battery Residues. Journal of Power Sources, 170, 210-215. https://doi.org/10.1016/j.jpowsour.2007.04.025

[13] Shuva, M.A.H. and Kurny, A. (2013) Hydrometallurgical Recovery of Value Metals from Spent Lithium Ion Batteries. Am. J. Mater. Eng. Technol., 1, 8-12.

[14] Nayaka, G.P., Manjanna, J., Pai, K.V., Vadavi, R., Keny, S.J. and Tripathi, V.S. (2015) Recovery of Valuable Metal Ions from the Spent Lithium-Ion Battery Using Aqueous Mixture of Mild Organic Acids as Alternative to Mineral Acids. Hydrometallurgy, 151, 73-77. https://doi.org/10.1016/j.hydromet.2014.11.006

[15] Li, L., et al. (2012) Ascorbic-Acid-Assisted Recovery of Cobalt and Lithium from Spent Li-Ion Batteries. Journal of Power Sources, 218, 21-27. https://doi.org/10.1016/j.jpowsour.2012.06.068

[16] Lee, C.-K. and Rhee, K. (2002) Preparation of $\mathrm{LiCoO}_{2}$ from Spent Lithium-Ion Batteries. Journal of Power Sources, 109, 17-21. https://doi.org/10.1016/S0378-7753(02)00037-X

[17] Shin, S.M., Kim, N.H., Sohn, J.S., Yang, D.H. and Kim, Y.H. (2005) Development of a Metal Recovery Process from Li-Ion Battery Wastes. Hydrometallurgy, 79, 172 181. https://doi.org/10.1016/j.hydromet.2005.06.004

[18] Suresh, P., Rodrigues, S., Shukla, A.K., Shivashankar, S.A. and Munichandraiah, N. (2002) Synthesis of $\mathrm{LiCo}_{1}-\mathrm{xNixO}_{2}$ from a Low Temperature Solution Combustion Route and Characterization. Journal of Power Sources, 112, 665-670. https://doi.org/10.1016/S0378-7753(02)00472-X

[19] Li, J., Zhao, R., He, X. and Liu, H. (2009) Preparation of $\mathrm{LiCoO}_{2}$ Cathode Materials from Spent Lithium-Ion Batteries. Ionics, 15, 111-113. https://doi.org/10.1007/s11581-008-0238-8 